\title{
PACLOBUTRAZOL FOR HEIGHT CONTROL OF PETUNIAS
}

\author{
Nora Francescangeli ${ }^{1 *}$, and Ana Zagabria ${ }^{1}$
}

\begin{abstract}
A B S T RA C T
The effects of paclobutrazol on the height of Petunia $\times$ hybrida hort. ex E. Vilm. were studied. An experiment on 'Bravo F1' was performed at the National Institute for Agricultural Technology (INTA), San Pedro

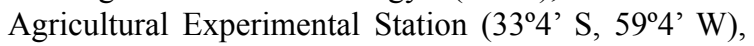
Buenos Aires Province, Argentina, in the spring of 2006. Treatments consisted of three colours of flower (white, red and blue), four concentrations of paclobutrazol by irrigation $\left(0,5,10\right.$ and $15 \mathrm{mg} \mathrm{L}^{-1}$ and three application times (at 10-12, 18-20 and 26-28 leaves). Height at 45 $\mathrm{d}$ after transplanting (dat), days to appearance, opening and fall of the first flower and number of flowers at 21 and 45 dat were registered. Differences between control plants due to flower colour were detected, and would indicate the need of a differential management: at 45 dat, the height of red-flowered plants $(22.3 \mathrm{~cm})$ was less $(\mathrm{P}<0.05)$ than white- $(25.2 \mathrm{~cm})$ or blue-flowered plants $(26.4 \mathrm{~cm})$. Paclobutrazol allowed for reducing height in all treated plants. The minimal concentrations that induced maximum effects were: $10 \mathrm{mg} \mathrm{L}^{-1}$ for blueflowered plants ( $56 \%$ shortening), $5 \mathrm{mg} \mathrm{L}^{-1}$ for whiteflowered plants ( $40 \%$ shortening) and $10 \mathrm{mg} \mathrm{L}^{-1}$ for redflowered plants ( $38 \%$ shortening). In order to minimize the slightly deleterious effects detected in the number of blue and red flowers at 45 dat, early application would be advisable (10-12 leaves) for blue-flowered plants and more delayed (at 18-20 leaves) for red-flowered plants.
\end{abstract}

Key words: plant growth regulator, plant architecture, flower colour, application time, Petunia $\times$ hybrida.

\section{INTRODUCTION}

The petunia is one of the most popular warm-season plants in the world owing to its versatility and variety. Since the 1970s the species has been submitted to continuous improvements, until today there is an ample range of colours among garden plant, with two growing habits (free-standing and hanging) and of hybrids of simple and double plants (between 400 and 500 cultivars) (Kessler, 1998). Like other potted plant species, the petunia has become a challenge for the flower-growers who seek to increase the quality of their production with lower and more compact plants.

The growth habits of this species respond to temperature and light. At less than $16^{\circ} \mathrm{C}$, the plant tends to branch out and become compact. At temperatures between 16 and $24{ }^{\circ} \mathrm{C}$, the growth habit depends on the number of hours of light; with less than $12 \mathrm{~h}$ of light, a single stem with a simple flower is produced, and over $24^{\circ} \mathrm{C}$, the plants will always tend to grow in height with few branches (Adams et al., 1998)

Because of this, for spring-summer production, when greenhouse temperatures in the northern region of Buenos Aires Province easily exceed $24{ }^{\circ} \mathrm{C}$ (Francescangeli, 1995), it is necessary to use physical or chemical methods that promote ramification and more compact growth. Among the physical methods, pinching back is the most widely used, but it causes lesions that can open the way to diseases (Bailey and Whipker, 1998). Among the chemical methods to control height are growth regulators (Latimer, 2001).

Paclobutrazol (2RS,3RS)-1-(4-chlorofenil)-4,4-dimetil2-(1H-1,2,4-triazol-1-yl)pentan-3-ol) is a growth regulator used to reduce the elongation of the stem of many potted plants (Runkle, 2002). Its effectiveness has been demonstrated with different sprayed herbaceous plants, including $P$. $\times$ hybrida (Barrett and Nell, 1992). It is known that the best means of paclobutrazol translocation is xylem (Rademacher, 2000; Whipker et al., 2003), so irrigation would be a better means of application than foliar aspersion.

\footnotetext{
${ }^{1}$ Instituto Nacional de Tecnología Agropecuaria, Estación Experimental Agropecuaria San Pedro, Ruta 9 km 170, CP 2930 San Pedro, Argentina. E-mail: nfrances@correo.inta.gov.ar *Corresponding author.

Received: 20 September 2007. Accepted: 23 November 2007.
} 
The objective of the work was to obtain information about the effects of paclobutrazol on the architecture of petunia plants during the spring season in the northern region of Buenos Aires Province, through the measurement of height and flowering parameters.

\section{MATERIALS AND METHODS}

The experiment was done at the Instituto Nacional de Tecnología Agropecuaria (INTA), San Pedro Agricultural Experimental Station, Buenos Aires Province, Argentina ( $33^{\circ} 4^{\prime} \mathrm{S}, 59^{\circ} 4^{\prime} \mathrm{W}$ ), during the spring of 2006 . The petunia cultivar used was Bravo F1 (Syngenta Seeds B.V.) White, Red and Blue (variations of the same cultivar that do not differ in the vegetative state). Transplanting was done on September 28, from trays with 240 seedlings, at the stage of two true leaves, buyed in a commercial nursery.

In a factorial experimental design three flower colours (white, red and blue) were considered as treatments of; four concentration of paclobutrazol: $0,5,10$ and 15 $\mathrm{mg} \mathrm{L}^{-1}$; and three application times: 1) 10-12 leaves, October 2, 2006, 4 days after transplanting (dat); 2) 18-20 leaves, October 9, 2006, 11 dat; and 3) 26-28 leaves, October 16, 2006, 18 dat.

Paclobutrazol (Kult'r S.C 25\% i.a., Agrimarketing S.A.) was applied by irrigation: $100 \mathrm{~cm}^{3}$ of solution for each plant. On each occasion the remaining plants were irrigated with $100 \mathrm{~cm}^{3}$ of water. The plants were trained in pots of $1 \mathrm{~L}$ capacity with a commercial substrate composed of different kinds of peat, worm humus and perlite (Grow Mix ${ }^{\circledR}$ Standard, Terrafertil S.A., Moreno, Argentina) (apparent density $0.083 \mathrm{~kg}$ $\mathrm{m}^{3}$; air porosity $22.4 \%$; water retention $61.7 \%$ ). The pots were placed in a greenhouse table, at a density of 55.5 plants $\mathrm{m}^{-2}$, with localized drip irrigation.

A randomized block design was applied, with 10 plants per treatment and with three replications. The following were evaluated in all plants: days to first visible appearance of flower buds; days to opening of the first flower bud; days to the fall of the first flower; number of open flowers at 21 dat and at 45 dat (open flowers present at those times); and plant height at 45 dat. The plants were examined daily to detect the presence of pests and diseases. Prior to the appearance of Liriomiza spp., abamectin was applied at 1.8\% (Segade, 2007, Entomology Laboratory, INTA EEA San Pedro, personal communication).
The SAS program (SAS Institute, 1989) was used for the statistical analysis of the data. The non-aditivity Tukey test was applied to confirm the normal distribution of the data, which was submitted to a variance analysis $(\alpha=0.05)$. The treatments were compared with the Tukey test for adjusted means $(\alpha=0.05)$.

\section{RESULTS AND DISCUSSION}

The effects of the concentrations and time of application of paclobutrazol, which in all cases were done after the appearance of the first floral bud, were analysed independently for each flower colour.

Given that the plants reached the state for application late (26-28 leaves) at 18 dat, the record for comparison of the concentrations and application times of paclobutrazol does not include the number of flowers at 21 dat, considering that the period of 3 days was insufficient for effects to be evident.

No significant interaction was detected between the concentrations and the time of application for any of the measured parameters. It was assumed that tendencies of differences among concentrations were similar for each of the application times and that the tendencies of differences among the application times were similar for each of the concentrations.

\section{Effects of flower colour}

Differences were detected among the control plants owing to the flower colour (Table 1). Although the time of the visible appearance and opening of the first flower bud were similar, the first red flower fell, with a significant difference of 1.5 to 2 days before the reds and blues.

At 21 dat the white-flowered plants had more open flower buds (2.5) than red-flowered (1.9) and blueflowered plants (1.9), but at 45 dat, the red-flowered plants showed the greatest number of open flower buds (17.8 vs. 14.7 blue and 14.5 white). At 45 dat, the height of plants with red flowers $(22.3 \mathrm{~cm})$ was significantly lower than those of the plant with white $(25.2 \mathrm{~cm})$ or blue flowers $(26.4 \mathrm{~cm})$.

\section{Effects of the concentrations and time of application of paclobutrazol for each flower colour} Blue flowers plants. The early application of paclobutrazol (10-12 leaves), compared to the earlier applications, delayed the colouring of the first flower 
bud by around 2 days and their fall by between 2 and 3 days. The plants treated early showed the largest number of flowers at 45 dat. At 45 dat all the concentrations had reduced the number of open flower buds in comparison to the control plants by 1.5 to 2.5 flowers (Table 2 ).

Paclobutrazol produced a reduction in plant height by $50 \%$ or more ( 26.4 vs. $13.5 \mathrm{~cm}$ or less). Results from concentrations of 10 and $15 \mathrm{mg} \mathrm{L}^{-1}$ did not differ between them and were the most effective. With the delay in the application, the effects on the final height were less at all concentrations.

Consequently, to achieve the maximum height reduction in blue-flowered plants with the minimum effect on the number of flowers, early application of paclobutrazol at 10 or $15 \mathrm{mg} \mathrm{L}^{-1}$ would be best

White flowes plants. Paclobutrazol did not have effects on time of the first flower bud nor on the number of opened flowers at 45 dat. The early application of paclobutrazol (10-12 leaves) delayed the fall of flower buds by between 2 and 3 days (Table 3 ).

All the concentrations reduced plant height at 45 dat by around $40 \%$ (25.2 vs. $15.4 \mathrm{~cm})$, with the applications at states of 10 to 12 or 18 to 20 leaves showing no difference. With late application (26-28 leaves) less reduction in height was observed with all of the concentrations.

Consequently, to achieve the maximum reduction in plant height with white-flowered plants, the application should be made at the state of 18-20 leaves with $5 \mathrm{mg} \mathrm{L}^{-1}$.

Red flowers plants. The early application of paclobutrazol (10-12 leaves) delayed the appearance of the colour of the first flower bud by around 2.5 to 3.5 days, the fall of the first flower bud by between 3 and 4 days and decreased the number of open flowers at 45 dat. Only with the concentration of $15 \mathrm{mg} \mathrm{L}^{-1}$ was a slight delay

Table 1. Effects of flower colour on the measured parameters of Petunia $\times$ grandiflora 'Bravo F1'.

\begin{tabular}{lcccc}
\hline Parameter & \multicolumn{3}{c}{ Flower colour } & VC \\
\cline { 2 - 4 } & Red & White & Blue & \\
\hline Days to appearance of the $1^{\text {st }}$ bud & 12.8 & 12.7 & 12.9 & 9.5 \\
Days to the $1^{\text {st }}$ bud with colour & 20.7 & 20.0 & 21.0 & 8.9 \\
Days to the fall of the $1^{\text {st }}$ bud & $26.1 \mathrm{~b}$ & $28.0 \mathrm{a}$ & $27.5 \mathrm{a}$ & 11.4 \\
Number of opened flowers at 21 dat & $1.9 \mathrm{~b}$ & $2.5 \mathrm{a}$ & $1.9 \mathrm{~b}$ & 12.3 \\
Number of opened flowers at 45 dat & $17.8 \mathrm{a}$ & $14.5 \mathrm{~b}$ & $14.7 \mathrm{~b}$ & 10.6 \\
Plant height at 45 dat, cm & $22.3 \mathrm{~b}$ & $25.2 \mathrm{a}$ & $26.4 \mathrm{a}$ & 11.0 \\
\hline
\end{tabular}

Distinct letters in the same row indicate statistical differences according to the Tukey test for adjusted means $(\alpha=0.05)$. dat: days after transplanting; VC: variation coefficient.

Table 2. Effects of application time and concentration of paclobutrazol on the measured parameters of Petunia $\times$ grandiflora 'Bravo F1' Blue.

\begin{tabular}{|c|c|c|c|c|c|}
\hline \multirow[t]{2}{*}{ Parameter } & \multicolumn{4}{|c|}{ Application time } & \multirow[t]{2}{*}{ VC } \\
\hline & 10-12 leaves & 18-2 & & 26-28 leaves & \\
\hline Days to the $1^{\text {st }}$ bud with colour & $23.2 \mathrm{a}$ & & & $21.0 \mathrm{~b}$ & 7.6 \\
\hline Days to the fall of the $1^{\text {st }}$ bud & $30.2 \mathrm{a}$ & & & $26.8 \mathrm{~b}$ & 7.8 \\
\hline Number of opened flowers at 45 dat & $13.3 \mathrm{a}$ & & & $12.9 \mathrm{~b}$ & 10.2 \\
\hline Height of the plants at 45 dat, $\mathrm{cm}$ & $14.2 \mathrm{c}$ & & & $17.0 \mathrm{a}$ & 11.8 \\
\hline \multirow[t]{2}{*}{ Parameter } & \multicolumn{4}{|c|}{ Concentrations of paclobutrazol $\left(\mathrm{mg} \mathrm{L}^{-1}\right)$} & VC \\
\hline & $\mathbf{0}$ & 5 & 10 & 15 & \\
\hline Days to the $1^{\text {st }}$ bud with colour & $21.1 \mathrm{~b}$ & $21.5 \mathrm{ab}$ & $22 \mathrm{a}$ & $22.3 a$ & 7.6 \\
\hline Days to the fall of the $1^{\text {st }}$ bud & $27.5 \mathrm{~b}$ & $28.0 \mathrm{ab}$ & $29 \mathrm{a}$ & $28.7 \mathrm{ab}$ & 7.8 \\
\hline Number of opened flowers at 45 dat & $14.7 \mathrm{a}$ & $12.2 b$ & $12.2 \mathrm{~b}$ & $12.1 \mathrm{~b}$ & 10.2 \\
\hline Height of the plants at 45 dat, $\mathrm{cm}$ & $26.4 \mathrm{a}$ & $13.5 \mathrm{~b}$ & $11.7 \mathrm{c}$ & $11.3 \mathrm{c}$ & 11.8 \\
\hline
\end{tabular}

Distinct letters in the same row indicate statistical differences according to the Tukey test for adjusted means $(\alpha=0.05)$. dat: days after transplanting; VC: variation coefficient. 
in the appearance of the first flower bud observed. The number of open flowers at 45 dat was less with any of the concentrations of paclobutrazol in comparison to the control (Table 4).

All of the concentrations reduced plant height, at 45 dat by $35 \%$ or more ( 22.3 vs. $15.1 \mathrm{~cm}$ or less), with the treatments of 10 and $15 \mathrm{mg} \mathrm{L}^{-1}$ being the most effective, but without differences among the application times. Consequently, to achieve the maximum height reduction in red flowered plants, with the minimum effect on the number of flowers, the application of concentrations of 10 or $15 \mathrm{mg} \mathrm{L}^{-1}$ of paclobutrazol in plants with 18 to 20 leaves would be best.

Runkle (2002) demonstrated the height reduction of the petunias when paclobutrazol was applied in different growth states with concentrations that varied between 2 and $12 \mathrm{mg} \mathrm{L}^{-1}$ and even it did not confirm a reduction in the number of flowers, a delay in their appearance was observed with $8 \mathrm{mg} \mathrm{L}^{-1}$.

In the present study the application of this regulator by irrigation reduced plant height with application of $5 \mathrm{mg}$ $\mathrm{L}^{-1}$; and the lesser number of flowers registered at 45 dat for the blues and reds could possibly be due to a delay in their appearance. Using lower concentrations would probably also have produced observable effects, which is especially useful for the white-flowered plants, given that in the case of the red and blue-flowered plants the maximum reduction was produced with $10 \mathrm{mg} \mathrm{L}^{-1}$.
Million et al. (1998) found that the concentration of paclobutrazol required to reach similar levels of height control with petunias increased by even more than 14 times in function of increasing the proportion of bark pine compost according to the proportion of peat in the components of the substrate.

Di Benedetto and Molinari (2007) demonstrated that the height of the petunia plant increases with the increased total porosity of the substrate, which negatively influences the effectiveness of the paclobutrazol. The commercial substrate used in the present experiment had a porosity of $22.4 \%$, which coincides with lower limit of the porosity range evaluated by these authors. As it is considered a low value, it should not have had a major influence on the elongation of the plants, and consequently did not have an influence on the effects of paclobutrazol, but undoubtedly more experiments are required to explore the influence of this parameter.

Aspersion as a method of applying a regulator has practical advantages over irrigation in an operation on a commercial scale. Nevertheless, if the translocation route of this product is known (xylem for paclobutrazol [Rademacher, 2000]) the method chosen in this study is more efficient.

Adams et al. (1999) reported on the high sensitivity of the species to the interaction of light $x$ temperature in determining the duration of immature phase in which

Table 3. Effects of application time and concentration of paclobutrazol on the measured parameters of Petunia ×grandiflora 'Bravo F1' White.

\begin{tabular}{|c|c|c|c|c|c|}
\hline \multirow{2}{*}{ Parameter } & \multicolumn{4}{|c|}{ Application time } & \multirow{2}{*}{$\mathbf{V C}$} \\
\hline & 10-12 leaves & 18-2 & & 26-28 leaves & \\
\hline Days to the $1^{\text {st }}$ bud with colour & 21.3 & & & 20.3 & 6.6 \\
\hline Days to the fall of the $1^{\text {st }}$ bud & $30.9 \mathrm{a}$ & & & $28.1 \mathrm{c}$ & 6.5 \\
\hline Number of opened flowers at 45 dat & 14.6 & & & 15.2 & 10.7 \\
\hline Height of the plants at 45 dat, $\mathrm{cm}$ & $17.2 \mathrm{~b}$ & & & $18.3 \mathrm{a}$ & 8.4 \\
\hline \multirow[t]{2}{*}{ Parameter } & \multicolumn{4}{|c|}{ Concentrations of paclobutrazol $\left(\mathrm{mg} \mathrm{L}^{-1}\right)$} & $\mathbf{V C}$ \\
\hline & $\mathbf{0}$ & 5 & 10 & 15 & \\
\hline Days to the $1^{\text {st }}$ bud with colour & 20.0 & 20.9 & 20.3 & 20.8 & 6.6 \\
\hline Days to the fall of the $1^{\text {st }}$ bud & $28.1 b$ & $29.7 \mathrm{a}$ & $29.7 \mathrm{a}$ & $30.3 \mathrm{a}$ & 6.5 \\
\hline Number of opened flowers at 45 dat & 14.5 & 14.8 & 14.5 & 14.0 & 10.7 \\
\hline Height of the plants at 45 dat, $\mathrm{cm}$ & $25.2 \mathrm{a}$ & $15.4 \mathrm{~b}$ & $15.2 \mathrm{~b}$ & $14.3 \mathrm{~b}$ & 8.4 \\
\hline
\end{tabular}

Distinct letters in the same row indicate statistical differences according to the Tukey test for adjusted means $(\alpha=0.05)$. dat: days after transplanting; VC: variation coefficient. 
Table 4. Effects of application time and concentration of paclobutrazol on the measured parameters of Petunia $\times$ grandiflora 'Bravo F1' Red.

\begin{tabular}{|c|c|c|c|c|c|}
\hline \multirow[t]{2}{*}{ Parameter } & \multicolumn{4}{|c|}{ Application time } & \multirow[t]{2}{*}{ VC } \\
\hline & 10-12 leaves & 18-21 & & 26-28 leaves & \\
\hline Days to $1^{\text {st }}$ bud with colour & $23.4 \mathrm{a}$ & & & $19.9 \mathrm{~b}$ & 8.5 \\
\hline Days to the fall of the $1^{\text {st }}$ bud & $29.9 \mathrm{a}$ & & & $25.7 \mathrm{~b}$ & 8.7 \\
\hline Number of opened flowers at 45 dat & $12.9 \mathrm{~b}$ & & & $14.2 \mathrm{a}$ & 16.0 \\
\hline Height of plant at 45 dat, $\mathrm{cm}$ & 15.9 & & & 16.5 & 9.9 \\
\hline \multirow[t]{2}{*}{ Parameter } & \multicolumn{4}{|c|}{ Concentrations of paclobutrazol $\left(\mathrm{mg} \mathrm{L}^{-1}\right)$} & \multirow[t]{2}{*}{ VC } \\
\hline & $\mathbf{0}$ & 5 & 10 & 15 & \\
\hline Days to the $1^{\text {st }}$ bud with colour & $20.7 \mathrm{a}$ & $20.8 \mathrm{a}$ & $21.5 \mathrm{ab}$ & $22.7 b$ & 8.5 \\
\hline Days to the fall of the $1^{\text {st }}$ bud & $26.1 \mathrm{~b}$ & $26.5 b$ & $27.8 \mathrm{ab}$ & $29.4 \mathrm{a}$ & 8.7 \\
\hline Number of opened flowers at 21 dat & $1.9 \mathrm{a}$ & $1.6 \mathrm{ab}$ & $1.5 b$ & $1.3 \mathrm{~b}$ & 9.2 \\
\hline Number of opened flowers at 45 dat & $17.7 \mathrm{a}$ & $13.9 \mathrm{~b}$ & $13.1 \mathrm{~b}$ & $11.6 \mathrm{~b}$ & 16.0 \\
\hline Height of the plant at 45 dat, $\mathrm{cm}$ & $22.3 \mathrm{a}$ & $15.1 \mathrm{~b}$ & $13.8 \mathrm{c}$ & $13.8 \mathrm{c}$ & 9.9 \\
\hline
\end{tabular}

Distinct letters in the same row indicate statistical differences according to the Tukey test for adjusted means $(\alpha=0.05)$. dat: days after transplanting; VC: variation coefficient.

the plant remains in the state of flowering: from 23 days with $2.6 \mathrm{MJ} \mathrm{m}^{-2} \mathrm{~d}^{-1}$ to 36 days with $1.6 \mathrm{MJ} \mathrm{m}^{-2}$ $\mathrm{d}^{-1}$, and for the same light integral of light $(2.6 \mathrm{MJ}$ $\left.\mathrm{m}^{-2} \mathrm{~d}^{-1}\right)$ it was accelerated with $21^{\circ} \mathrm{C}(12.5$ days $)$ in comparison to $13.5^{\circ} \mathrm{C}(21$ days $)$ and a $28.3^{\circ} \mathrm{C}(17.6$ days). This sensitivity represents another variable for consideration of the response of the petunia to treatment with growth regulators. Consequently, the behaviour of the three colours of 'Bravo F1' in other climatic situations should be studied.

The contribution of this work was to demonstrate the effectiveness of paclobutrazol in the reduction of the height of petunia plants, applied by irrigation to ensure the most efficient form of translocation and the need to adjust handling for the species according to flower colour. Future trials could evaluate the differences if aspersion is used.

\section{CONCLUSIONS}

The results obtained indicate the need for different management of the hybrid petunia cultivar Bravo F1 according to the flower colour if it is planned to apply paclobutrazol as a growth regulator.

The use of paclobutrazol applied by irrigation allowed for reducing the height of plants at 45 dat in all three flower-colours.
The minimal concentrations with which the maximum effects were observed were: $10 \mathrm{mg} \mathrm{L}^{-1}$ for blue-flowered plants (56\% reduction in height) and red-flowered plants ( $38 \%$ reduction in height), and $5 \mathrm{mg} \mathrm{L}^{-1}$ for the white-flowered plant ( $40 \%$ reduction in height).

Slightly deleterious effects were detected in terms of the number of flowers at 45 dat for blue- and red-flowered plants. With the aim of minimizing these effects, early application (10-12 leaves) with blue-flowered plants is advisable, and later application (18-20 leaves) for the red-flowered plants.

\section{R E S U M E N}

Paclobutrazol para el control de la altura de petunia. Nora Francescangeli ${ }^{1 *}$, y Ana Zagabria ${ }^{1}$. Para estudiar los efectos del paclobutrazol en la altura de petunia (Petunia $\times$ hybrida hort. ex E. Vilm.), se desarrolló un experimento sobre el cv. Bravo F1 en la Estación

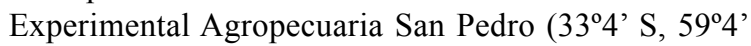
O) del Instituto Nacional de Tecnología Agropecuaria (INTA), Provincia de Buenos Aires, Argentina durante la primavera de 2006. Los tratamientos consistieron en tres colores de flor (blanco, rojo y azul), cuatro concentraciones de paclobutrazol aplicadas por riego $(0$; $5 ; 10$ y $\left.15 \mathrm{mg} \mathrm{L}^{-1}\right)$ y tres momentos de aplicación (10$12,18-20$ y $26-28$ hojas). Se registraron: altura 45 días después del trasplante (dat), días a aparición, apertura y 
caída de primera flor y número de flores a 21 y 45 dat. Se detectaron diferencias entre testigos debidas al color de flor, resultado que indicaría la necesidad de un manejo diferencial: a 45 dat la altura de plantas con flores rojas $(22,3 \mathrm{~cm})$ fue menor a la de plantas con flores blancas $(25,2 \mathrm{~cm})$ o azules $(26,4 \mathrm{~cm})$. El paclobutrazol redujo la altura en todas las plantas tratadas. Las concentraciones mínimas con las que se observaron los máximos efectos fueron: $10 \mathrm{mg} \mathrm{L}^{-1}$ para plantas de flor azul (reducción $56 \%$ ), $5 \mathrm{mg} \mathrm{L}^{-1}$ para plantas de flor blanca (reducción
$40 \%$ ) y $10 \mathrm{mg} \mathrm{L}^{-1}$ para plantas de flor roja (reducción $38 \%$ ). Para minimizar efectos levemente deletéreos detectados en número de flores azules y rojas a 45 dat; sería conveniente para azul una aplicación temprana (10-12 hojas) y para rojo una más tardía (desde 18-20 hojas).

Palabras clave: regulador de crecimiento, arquitectura de la planta, color de la flor, momento de aplicación, Petunia $\times$ hybrida.

\section{LITERATURE CITED}

Adams, S.R., P. Hadley, and S. Pearson. 1998. The effects of temperature, photoperiod and photosynthetic photon flux on the time to flowering of Petunia 'Express Blush Pink'. J. Amer. Soc. Hort. Sci. 123:577-580.

Adams, S.R., S. Pearson, P. Hadley, and W.M. Patefield. 1999. The effects of temperature and light integral on the phases of photoperiod sensitivity in Petunia $\mathrm{x}$ hybrida. Ann. Bot. 83:263-269.

Barret, J.E., and T.A. Nell. 1992. Efficacy of paclobutrazol and uniconazole on four bedding plant species. Hortic. Sci. 27:896-897.

Bailey, D.A., and B.E. Whipker 1998. Best management practices for plant growth regulators used in floriculture. Horticulture Information Leaflets 529. 4 p. North Carolina Cooperative Extension Service, North Carolina State University, Raleigh North Carolina, USA.

Di Benedetto, A., and J. Molinari. 2007. Influence of river waste-based media on efficacy of paclobutrazol in inhibiting growth of Petunia $\mathrm{x}$ hybrida. Int. J. Agric. Res. 2:289-295.

Francescangeli, N. 1995. Manejo del clima del invernadero para cultivo de tomate. $5^{\text {as }}$ Jornadas sobre Cultivos Protegidos, La Plata, 23 y 24 de noviembre. Universidad Nacional de La Plata, Buenos Aires, Argentina.

Kessler, Jr., J.R. 1998. Greenhouse production of petunia. Alabama Cooperative Extension System, Auburn University, Alabama, USA. ANR-1118. Available at http://www.aces.edu/pubs/docs/A/ANR-1118/ (Accessed 16 July 2007).
Latimer, J.G. 2001. Selecting and using plant growth regulators on floricultural crops. 21 p. Virginia Cooperative Extension, Publication 430-102. Virginia State University, Petersburg, Virginia, USA.

Million, J.B., Barret J.E., Nell T.A., and D.G. Clark. 1998. Influence of media components on efficacy of paclobutrazol in inhibiting growth of broccoli and petunia. HortScience 33:852-856.

Rademacher, W. 2000. Growth retardants: effects on gibberellin biosynthesis and other metabolic pathways. Annu. Rev. Plant Physiol. Plant Mol. Biol. 51:501531.

Runkle, E. 2002. Bonzi sprays on dianthus and petunia plugs. Michigan State University's Greenhouse Alert, Issue 4. Available at http://www.ipm.msu.edu/grnhouse02/ G01-4-02.htm\#1 (Accessed 12 July 2007).

SAS Institute. 1989. SAS/STAT User's guide. Version 6. $4^{\text {th }}$ ed. Vol. 2. 8846 p. SAS Institute, Cary, North Carolina, USA.

Whipker, B.E., J.L. Gibson, T.J. Cavins, I. McCall, and P. Konjoinan. 2003. Growth regulators. p. 85-112. Ball Redbook. Ball Publishing, Batavia, Illinois, USA. 